\title{
THE EFFECTIVENESS OF WHATSAPP GROUP CHAT FOR INTERNAL COMMUNICATION AT KADOKAWA GEMPAK STARZTM
}

\author{
Nadirah Binti Nissanto \\ Faculty of Development and Multicultural Studies \\ University College Sabah Foundation, Kota Kinabalu, Sabah, Malaysia \\ Email: nadirahn.ucsfmalaysia@gmail.com
}

\begin{abstract}
This study emphasizes on the proliferation of technological devices such as smartphones and the effectiveness of WhatsApp Group Chat in working organization such as Kadokawa Gempak Starz ${ }^{\mathrm{TM}}$ for Internal Communication. Technology is applied in work as they aid in solving problems and easy access to information. There were two research objectives which the study seeks to determine. First is to explain the adoption of WhatsApp Group Chat for Internal Communication through Technology Acceptance Model. Second, is to examine the challenges of using WhatsApp Group Chat for Internal Communication. The study employed a research design based on questionnaire with a total number of 120 respondents. Ultimately the findings showed that the respondents find it challenging to use WhatsApp Group Chat for Internal Communication and are on the fence about its usage for Internal Communication as well as the effectiveness to serve as a communication tool for internal Communication at Kadokawa Gempak Starz ${ }^{\mathrm{TM}}$, all of these variables will hugely impacted the behavioral intention towards WhatsApp Group Chat in the future.
\end{abstract}

Keywords: Internal Communication, WhatsApp, Technology, Effectiveness 


\section{Introduction}

This study highlights on WhatsApp. It is a mobile messaging service for smartphones which was initiated in 2009 which allow users to send out messages, video, images and also audio messages. It was developed by Jan Koum, a college dropout and self-taught engineer. He came to the United States all the way from Ukraine when he was a teenager. He developed the app as a way to communicate with his international friend. He later met with Brian Acton while working in Yahoo, which is now the cofounder of WhatsApp after helping him with getting money for investment (Olson, 2014).

The study emphasizes on the proliferation of technological devices such as smartphones and the effectiveness of messenger apps used in working organization for Internal Communication. Technology is applied in work as they aid in solving problems and easy access to information. Significant information can be shared through WhatsApp Group Chat with the purpose that every worker will get it too (Boswell \& Olson-Buchanan, 2007; Chesley et al., 2002). It has been proven that WhatsApp Group Chat boost the working performance as it allows easy communication between worker regardless time and location (Day et al., 2012).

Although, not all technology is suitable for certain organization. Not all can commit to solely use messenger apps such as WhatsApp just to discuss about work and share thoughts and exchange opinions for the betterment of their working organization. No doubt some might go off out of topic or even use the messenger apps to text their families and friends during working hours. The implementation of WhatsApp in working organization is still debated as some have debated that it might be misused. Although, it has become a communication tool for everyone as it is user-friendly and free as long as there is an Internet connection.

\section{About Kadokawa Gempak Starz ${ }^{\mathrm{TM}}$}

Kadokawa Gempak Starz ${ }^{\mathrm{TM}}$ is a prominent producer of multilingual comics and magazines in Southeast Asia. First enumerated as Gala Unggul Sdn. Bhd. in 2002, the company was attained by Japanese entertainament content provider, Kadokawa Corporation in 2015 and consequently rebranded as Kadokawa Gempak Starz ${ }^{\mathrm{TM}}$ in January 2016. 
Headquartered in Kuala Lumpur, Malaysia, the company's fundamental business is the publishing and distribution of comics and magazines in three languages which are Bahasa Malaysia, English, and Mandarin. Among the company's major brands are 'Learn More', 'Magic Bean' imprints of educational comics series and light novels which include best-selling titles such as 'X-Venture', Candy' series, 'Sunny Junior' and many more.

\section{Internal Communication and Employee Communication}

Internal communication has been a crucial part of communication management thus as an example the topic of internal communication has regularly shown itself to be the top five most pressing issues in the European communication practice (European Communication Monitor, 2009/2010/2011) and has been emphasized as one of the key functions in The United States of America practice (Goodman et al., 2011). According to the report of Zerfass et al. (2014), the only way to help overcome the pressing issues are to focus on the top three out of ten issues mentioned in the report as follows; first, improving employee engagement and commitment; second, finding, developing and retaining top talent; and lastly, meeting communication needs in diverse cultures in global organizations.

Employee communication is often perceived as one of the key elements of an organizational strategy of employee involvement. Employee involvement "is an umbrella term covering a wide range of intended employer-led initiatives that are planned to inspire more active worker involvement in (organizational) matters" (Caldwell, 1993). The aim of these initiatives is "to raise the level of employee pledge to an organization" (Guest et al., 1993). These initiatives may comprise some or all of the following: first, "amplified information (flow) down the organization"; second, "amplified information (flow) up the organization"; third, "variations in job design"; fourth, monetary participation or involvement; and, fifth, deviations in management or administration style concerning additional participative method (Guest et al., 1993). Employee communication is undeniably vital in all of these sorts of involvement initiatives. 


\section{Whatsapp Group Chat For Internal Communication}

Adapting new technology in organization can give impacts in so many ways. First, it can help to improve workers working performance. For example, the use of smartphones can aid the speed of communication between workers and help to make better decision making in the workplace. Tasks can be divided smoothly and swiftly (Day A. et al, 2010). Second, it can help to boost organization productivity. As the workers can communicate much faster and with the aid of smartphones, information is just a click away. Meetings and decision making can be made anywhere and anytime regardless (Day A. et al, 2012). Third, faster task accomplishment can be achieved with smartphones, Internet connection as well as quick response through WhatsApp as an example between coworkers (Currie \& Eveline, 2011). Fourth, improved collaboration between workers as they have stated that communication gap is reduced by using smartphones to aid better communication.

\section{Technology Acceptance Model}

The Technology Acceptance Model was derived from the theory of reasoned action. It explains how users' assertiveness is closely link to their aims to perform responsibilities (Davis, 1989; Davis et al., 1989). This theory is the most accurately defined model explaining the acceptance of new IT technologies developed by Davis and his colleagues (Davis, 1989, 1993; Davis et al., 1989).

In the Technology Acceptance Model, there is the need to merge users' traits that reflects their readiness to use new technologies which include the conflicting positive and negative feelings toward the usage of technology. According to Parasuraman (2000), technology readiness reflects the complexity of users' traits and the Technology Acceptance Model form a much more detail construct than existing personality traits. The Technology Acceptance Model has been proven to be a useful theoretical model to aid comprehension and explain consumer's behavior toward technology acceptance (Baron et al., 2006; Legris et al., 2003).

\section{Research Design}

This study aims to explore the usage of Whatsapp Group Chat for internal communication. Hence, the researcher used the quantitative research method to conduct the research and operationalized the 
relevant variables. All data were collected by using self-administered questionnaire method for the interested variables and there were 120 respondents for this study.

All questionnaires were disseminated to the respondents and later collected back. The arranged questionnaires given to respondents are intended to stimulate specific information. The survey of questionnaires was distributed in eighteen departments of Kadokawa Gempak Starz ${ }^{\mathrm{TM}}$.

\section{Findings}

For Section A, basically, out of the 120 respondents, 117 respondents use WhatsApp. This equals to 42 male respondents and 75 female respondents. From the 117 respondents, 3 respondents do not use WhataApp Group Chat. This leaves 114 respondents that use Whatsapp Group Chat which includes 41 male respondents and 73 female respondents. Out of those 114 respondents, 6 respondents do not use WhatsApp Group Chat which includes 2 male respondents and 4 female respondents.

The Adoption of Whatsapp Group Chat For Internal Communication Through Technology Acceptence Model

For Section B, most of the respondents are still neutral about the usage of WhatsApp Group Chat for Internal Communication at Kadokawa Gempak Starz ${ }^{\mathrm{TM}}$ as it is a toss between 'slightly disagree' and 'slightly agree'.

For Section D, the majority of the respondents are neutral about the effectiveness of WhatsApp Group Chat for Internal Communication as majority of the respondents chosed 'slightly disgaree'. Thus, referring to the conceptual framework, since the respondents are neutral about the use and the effectiveness of WhatsApp Group Chat, this will somehow affect the attitude towards the use of WhatsApp Group chat as well as the behavioral intention towards WhatsApp Group Chat in the future.

\section{The Challenges of Using Whatsapp Group Chat for Internal Communication}

For Section C, the implementation of WhatsApp Group Chat for Internal Communication can be a challenge as the respondents circled agree the most in their questionnaire for Section C. Moreover, the respondents are still neutral about the use of WhatsApp Group Chat for Internal Communication. The 
respondents feel like not everyone is participative in WhatsApp Group Chat. They also prefer to meet face to face to discuss work rather than discussing it through WhatsApp Group Chat. Apart from that, the fact that WhatsApp is only usable with Internet and Wi-Fi connection. The respondents think it is very easy to slip out of topic during work related discussion through WhatsApp Group Chat.

\section{Discussion}

From the findings above, the researcher found out that the respondents are neutral about using WhatsApp Group Chat for Internal Communication at Kadokawa Gempak Starz ${ }^{\mathrm{TM}}$. Apart from that, a number of challenges were also highlighted by the respondents such as the respondents feel like not everyone is participative in WhatsApp Group Chat. They also prefer to meet face to face to discuss work rather than discussing it through WhatsApp Group Chat. Apart from that, the fact that WhatsApp is only useable with Internet and Wi-Fi connection. The respondents think it is very easy to slip out of topic during work related discussion through WhatsApp Group Chat. According to the Technology Acceptance Model, as perceived usefulness and perceived ease of use of WhatsApp Group Chat will somehow affects attitude towards using and behavioral intention towards WhatsApp Group Chat thus as the result of use and effectiveness of WhatsApp Group Chat are neutral will somehow give impacts to the attitude towards using and behavioral intention towards WhatsApp Group Chat.

Consumers' adaptation towards new technologies has been a major apprehension for researchers as the increase of technologies out there are plenty. Researches rely on Technology Acceptance Model to further explain the relationship between consumers and technologies.

Basically, the respondents were neutral about the effectiveness of WhatsApp Group Chat for Internal Communication at Kadokawa Gempak Starz ${ }^{\mathrm{TM}}$. The respondents find it challenging for them to use WhatsApp Group Chat in the organization thus deeming WhatsApp as not effective for Internal Communication at Kadokawa Gempak Starz ${ }^{\mathrm{TM}}$. 


\section{Conclusion}

Basically, since the respondents find it challenging to use WhatsApp Group Chat for Internal Communication and are neutral about its usage for Internal Communication as well as the effectiveness to serve as a communication tool for internal Communication at Kadokawa Gempak Starz ${ }^{\mathrm{TM}}$, all of these variables will hugely impacted the behavioral intention towards WhatsApp Group Chat in the future. Not saying that it is not effective at all but the respondents do not also rely on WhatsApp Group Chat for Internal Communication.

It can be concluded that since the respondents find it challenging to use WhatsApp Group Chat for Internal Communication, the use of WhatsApp Group Chat for Internal Communication is deemed not effective at Kadokawa Gempak Starz ${ }^{\mathrm{TM}}$.

\section{Recommendations}

This study can be further extended using a qualitative research methodology in order to better understand the use of WhatsApp Group Chat for Internal Communication or perhaps other social media apps for Internal Communication. Apart from that, an extended study about the topic will further explain why respondents are neutral about WhatsApp Group Chat for Internal Communication. Furthermore, this research topic can also be implemented in other working organization from a different background as well as from a different industry in regards of the use of WhatsApp Group Chat for internal Communication. 


\section{References}

A. Santos , J. (1999). Cronbach's Alpha: A Tool for Assessing the Reliability of Scales. Journal of Extension.

Aharony, N., \& Gazit, T. (2016). The importance of the Whatsapp family group: an exploratory analysis. Aslib Journal of Information Management, 174 - 192.

Anderson , K. E. (2016). Getting acquainted with social networks and apps: WhatsApp-ening with mobile instant messaging? Library Hi Tech News, pp. 11 - 15.

Ashcraft, K., Khun, T., \& Cooren, F. (2009). Constitutional amendements: 'Materializing' organizational communication. The Accademy of Management Annuals, 1-64.

Association, M. D. (2016, August 3-4). 2016 Malaysia Digital Landscape. Retrieved from www.malaysiandigitalassociation.org.my

Barney, J. (1991). Firm resources and sustained competitive advantage. Journal of Management, 99120.

Baron, S., Patterson, A., \& Harris, K. (2006). Beyond technology acceptance: understanding consumer practic. International Journal of Service Industry Management, 111-135.

Beaver, L. (2017, January 6). Here's how millennials are impacting the future of communication. Retrieved from Business Insider: http://www.businessinsider.com/heres-how-millennials-areimpacting-the-future-of-communication-2017-1? IR =T\& $=\mathrm{US} \& \mathrm{IR}=\mathrm{T}$

Bentele, G. (2006). Interne Organisationskommunikation. Wiesbaden: VS Verlag fur Sozialwissenschaften.

Berkman, L., \& Glass, T. (2000). Social integration, social networks, social support and health. New York: Oxford University Press.

Bless, C., \& Higson-Smith, C. (2000). Fundamentals of Social Research Methods: An African Perspective. South Africa: Juta and Company Ltd.

Broughton, A., Higgins, T., Hicks, B., \& Cox, A. (2009). Workplaces and Social Networking: The Implications for Employment Relations. Brighton: Acas Research Publications.

Caldwell, R. (1993). Is anyone listening? Communicating change to employees. Journal of Strategic Change, 83-7.

Chiu, C. H. (2006). Understanding knowledge sharing in virtual communities: an integration of social capital and social cognitive theories. Decision Support Systems, 1872-1888.

Church, K., \& Oliveira, R. (2013 ). What's up with whatsapp?: comparing mobile instant messaging behaviors with traditional SMS. MobileHCI '13 Proceedings of the 15th international conference on Human-computer interaction with mobile devices and services (pp. 352-361 ). New York: ACM. 
Clampitt, P. (2004). Communicating for Managerial Effectiveness. London: Sage Publications Ltd.

Clifford J., D., Michael L., H., \& Hosp, J. L. (2008). Designing and Conducting Research in Education. California: Sage.

Cobb, S. (1976). Social support as a moderator of life stress. Psychosomatic Medicine, 300-314.

Cohen, S., \& Wills, T. (1985). Stress, social support, and the buffering hypothesis. Psychological Bulletin, 310-357.

Cohen, T., \& Ashby, W. (1985). Stress, social support and the buffering hypothesis. Psychological Bulletin, 310-357.

Coleman, J. (1988). Social capital in the creation of human capital. American Journal of Sociology, 95120.

Commission, M. C. (2016). INTERNET USERS SURVEY 2016: STATISTICAL BRIEF NUMBER TWENTY. Cyberjaya: Malaysian Communications and Multimedia Commission.

Currie, J., \& Eveline, J. (2011). E-technology and work/life balance for academics with young children. The International Journal of Higher Education and Educational Planning, 533-550.

Daniel, T. \&. (2012). Society for Human Resource Management. Retrieved from https://www.shrm.org/

Davis, F. (1989). Perceived usefulness, perceived ease of use, and user acceptance of information technology. MIS Quarterly, 319-340.

Davis, F. (1993). User acceptance of information technology: system characteristics, user perceptions and behavioral impacts. International Journal of Man-Machine Studies, 475-487.

Davis, F. B. (1989). User acceptance of computer technology: a comparison of two theoretical models. Management Science, 982-1003.

Day A, P. S. (2012). Perceived information and communication technology (ICT) demands on employee outcomes: The moderating effect of organizational ICT support. Journal of Occupational Health Psychology, 473-491.

Day A, S. N. (2010). Information and communication technology: Implications for job stress and employee well-being. New developments in theoretical and conceptual approaches to job stress, 317-350.

Dimitriadis, S., \& Kyrezis, N. (2010). Linking trust to use intention for technology-enabled bank channels: the role of trusting intentions. Psychology \& Marketing, 799-820.

DMR. (2015, January 25). Digital marketing ramblings. Retrieved from By the Numbers: 50 Amazing WhatsApp Statistics: http:/expandedramblings.com/index.php/whatsapp-statistics/\#.VB_

Dunkel-Schetter, C., \& Brooks, K. (2009). Encyclopedia of Human Relationships. California: Sage.

eMarketer. (2015). Retrieved from Mobile messaging to reach 1.4 Billion Worldwide in 2015: www.emarketer.com/Article/Mobile-Messaging-Reach-14-Billion-Worldwide-2015/1013215 
Facebook. (2014, February 19). Facebook to Acquire WhatsApp. Retrieved from Facebook Newsroom: http://newsroom.fb.com/news/2014/02/facebook-to-acquire-whatsapp/

Floyd J., F. (2009). Survey Research Methods: Volume 1 of Applied Social Research Methods. California: Sage.

Friedrich von den Eichen, S. K. (2008). Kernaspekte einer Innovationskultur. Dusseldorf: Symposion Publishing.

Goodman, M. G. (2011). CCI corporate communication practices and trends: United States - final report. New York: Corporate Communication International.

Granovetter, M. (1993). The Nature of Economic Relationships. New York: Russel Sage Foundation.

Grant, R. (1996). Toward a knowledge-based theory of the firm. Strategic Management Journal, 109122.

Grates, G. (2006, September). Are your employees working with the volume off? . Retrieved from Edelman Memo to Management: http://www.edelman.com/expertise/practices/employee_change/documents/Edelman_

Grunig, J. G. (2002). Excellent public relations and effective organisations: A study of communication management in three countries. London: Lawrence Erlbaum Associates Publishers.

Guest, D. P. (1993). "The impact of employee involvement on organizational commitment and 'them and us' attitudes. Industrial Relations Journal, 191-200.

Heath, R. (1994). Management of Corporate Communication. New York: Lawrence Erlbaum Associates.

Heide, M., \& Simonsson, C. (2011). Putting coworkers in the limelight: new challenges for communication professionals. International Journal of Strategic Communication, 201-220.

Järvinen, J., To“llinen, A., Karjaluoto,, H., \& Jayawardhena, C. (2012). Digital and social media marketing usage in B2B industrial section. Marketing Management Journal, 102-117.

James P., N. (2015). International Business Research. New York: M.E. Sharpe.

Kalla, H. (2005). Integrated internal communications: A multidisciplinary perspectives. Corporate Communication, 302-314.

Kawachi, I., \& Berkman, L. (2001). Social ties and mental health. Journal of Urban Health, 458-467.

King, W., \& He, J. (2006). A meta-analysis of the technology acceptance model. Information \& Management, 740-755.

Koum, J. (2013). WhatsApp. Retrieved from WhatsApp Blog: http://blog.whatsapp.com/index.php/2013/12/

Koum, J. (2017, February 20). WhatsApp Status. Retrieved from WhatsApp Blog: https://blog.whatsapp.com/10000630/WhatsApp-Status 